\title{
INVESTIGATION OF ENVIRONMENTAL IMPACTS ON SANDSTONE BLOCKS AT LUXOR TEMPLE AND CONCEPTS FOR CONSERATION
}

\section{Dr. Elashmawy Abd -Elkareem Ahmed}

\begin{abstract}
:
Sandstone blocks were used in the construction of Luxor temple. However, they, especialy cement materials, were at a great risk because of being affected by various deterioration factors. Groundwater started to rise in and around the temple, causing serious deterioration aspects of the blocks. Therefore, the current study was conducted to focus on the role of pores and cement regarding the deterioration process of sandstone blocks in the temlpe. In order to conduct systematic investigation, it adopted SEM - EDX, PLM and XRD. Also, physical and mechanical properties were examined to evaluate the components of the sandstone, under the present environmental conditions. It also interpreted the investigations of onsite evaluation tests (non- and less-destructive). It also focused on other methods, e.g. humidity and salt analysis. The study ended develops some recommendations that fit sandstone address in Luxor Temple.
\end{abstract}

\section{Keywords:}

Luxor temple, Sandstone blocks, Cement materials, Environmental, Decay, Load-bearing, Salts, Faults, cracks.

\footnotetext{
- Conservation department, Faculty of Archaeology, South Valley Univ., Qena, Egypt, 83523. Tel: 00201142941963,Email: elashmawyabdelkareem@yahoo.com
} 


\section{Introduction}

\subsection{Archaeological History and Architectural Description of Luxor Temple}

Luxor temple is located on the eastern bank of the Nile, near Luxor downtown. It covers an area of $14025 \mathrm{~m}^{2}$; it is $255 \mathrm{~m}$ long and $55 \mathrm{~m}$ wide (Fig.1\&2). It was mostly constructed of Nubian sandstone that was brought from Gebel el-Silsila quarries, Aswan [1], [2].Sandstone was not only dealt with as a building material, but was employed for many other purposes, such as statues and stelae, as well [3]. Because it was not carefully studied by many, the Current study tried to investigate sandstone blocks of Luxor temple. Unfortunately, they were in a very bad condition. Physiochemical factors, e.g. temperature, moisture, heavy rain water, salt weathering and Agricultural expansion in Luxor (Fig.3) played an important role in their deterioration, decreasing their physio-mechanical and chemical properties (Fig.7).Sandstone blocks in the temple were exposed to both internal and external weathering processes. Their interaction depended on the nature of the environment and their location within the building. There were two major causes of sandstones' deterioration in the temple; pollutants and crystallization of soluble salts (Fig.7, 9).

[1]Baines, J., Malek J., Cultural Atlas of Ancient Egypt, Checkmark Books, Rev. Ed., 2000, p. 240.

[2] Karem, M., (2013). Environmental Impact of Groundwater Rising Level on Archaeological Sites in Upper Egypt, Unpublished Ph.D. Thesis, Faculty of Science, South Valley University, Pp. 40-41

[3] Lucas, A., (1934). Ancient Materials \& Industries, London, P.371. 


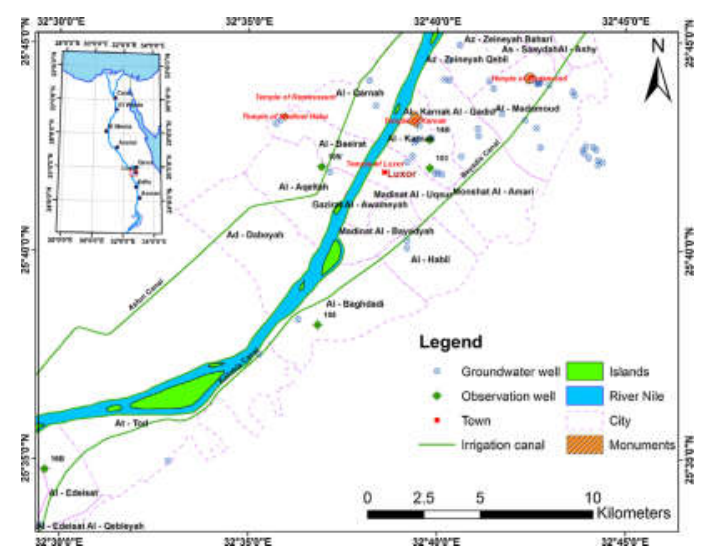

Fig. (1) Location map of the study's area[4]

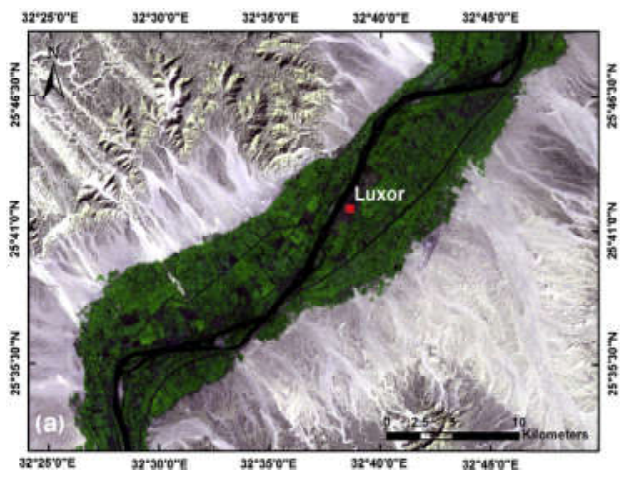

Fig. (3) The agricultural areas in green color from 1986 to 2011[5].

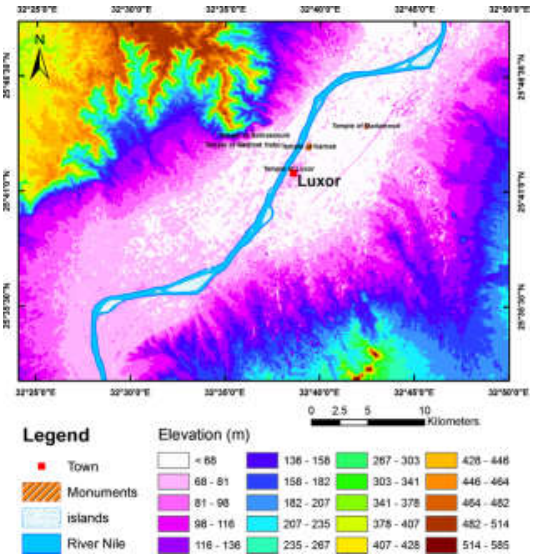

Fig. (2) Topography of Luxor area, depicted by ASTGTM [5].

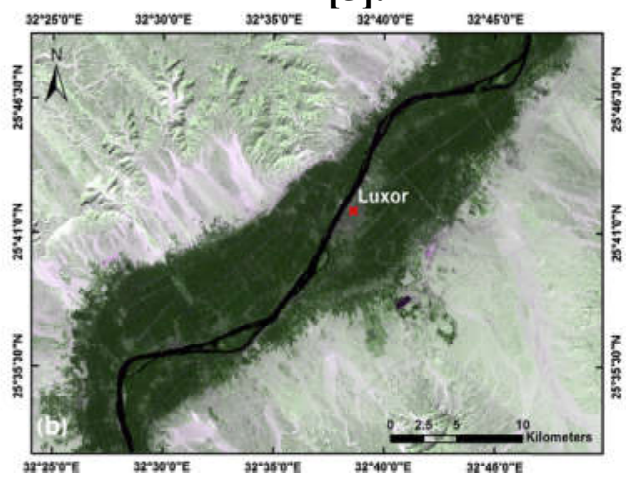

[4] Ayman, A., Graham E., Mohsen G., (2014). Water Use at Luxor, Egypt: Consumption Analysis and Future Demand Forecasting, Environ Earth Sci, PP.1041-1053.

[5] Ayman, A., Graham E., (2014). The Impact of Groundwater and Agricultural Expansion on the Archaeological Sites at Luxor, Egypt, Journal of African Earth Sciences, Vol. 95, 93-104. 


\section{Geologic setting and Hydrogeology}

Geologic setting of the study area has been studied by many authors, it is noted that the area's sedimentary composition can be classified (from top to base) into quaternary, tertiary and upper cretaceous rock units (Fig. 4). Quaternary rock units are divided into Holocene deposits (Arken formation; modern River Nile sediment) and Pleistocene deposits (Armant formation, Qena sand, Abassia formation and Wadi deposits). Tertiary rock units include Pliocene rocks (Madmoud formation) and the Lower Eocene -Palaeocene (Thebes's formation, Esna shale and Tarawan Chalk). Upper Cretaceous rocks include the Dakhla shale, Duwi formation and Qusir shale

[6], [7], [8] \& [9] (Fig.4).

The hydrogeological setting of the study area was well addressed by many authors [10] \& [11].The high level of ground water in the area results from the River Nile and its main canals used for irrigation. The main aquifers in this area are Pilo-pleistocene and Quaternary. The aquifer of Quaternary lies in the center of the Nile valley, occupying the cultivated lands on the banks of Nile. It can be divided into two parts; lower Pleistocene aquifer and

[6] Issawi, B., Hassan, M., \& Osman, R., (1978). Geological Studies in the Area of Kom Ombo, Eastern Desert, Egypt. Ann. Geol. Surv. Egypt, Vol.8, P. 187-235.

[7] Said, R., (1990). The Geology of Egypt, Egyptian General Corporation, Conoco Hurghada Inc. and Repsol Exploration, S.A., Balkema, Rotterdam, Brookfield, p.731.

[8] Issawi, B., \& McCauley J., (1992). The Cenozoic Rivers of Egypt: The Nile Problem, In: Freidman, R., Adams, B. (Eds.), the Followers of Hours: Studies Assoc. Public., No. 2, Oxford, PP.121-138.

[9] Wendorf, F., \& Schild, R., (2002). Implications of Incipient Social Complexity in the Late Neolithic in Egyptian Sahara. In: Friedman, R. (Ed.), Egypt and Nubia: Gifts of the Desert, London, pp. 13-20.

[10] Ismail, A., Anderson, NL., \& Rogers, D., (2005). Hydrogeophysical Investigation at Luxor, Southern Egypt, JEEG, Vol. 10, Issue 1, Pp. 35-49 .

[11] Salman A. Howari M., El-Sankary M., Wali, M., \& Saleh M., (2010). Environmental Impact and Natural Hazards on Kharga Oasis Monumental Sites, Western Desert of Egypt, Journal of African Earth Sciences, Vol.58, 341-353 . 
upper Holocene aquitard. It is a good source of water and it is fed by canals [12]. In this aquifer, ground water is pumped through pores, and water is transferred to the Nile [13]. The aquifer of Plio-Pleistocene is the secondary one in Luxor city and is represented by Armant Formation [15] (Fig.5).

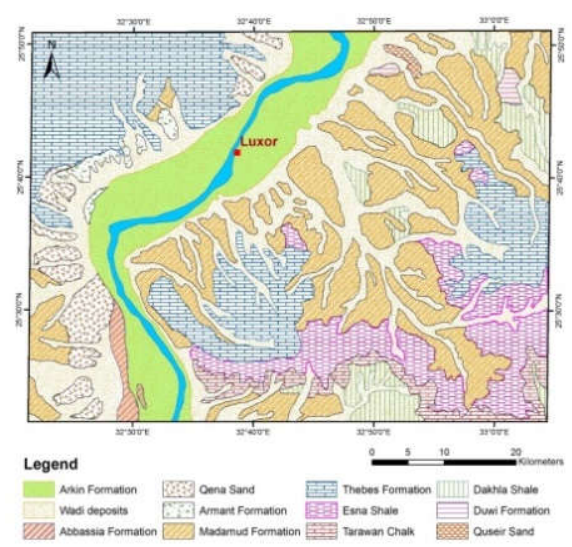

Fig. (4) Geology of Luxor City [14].

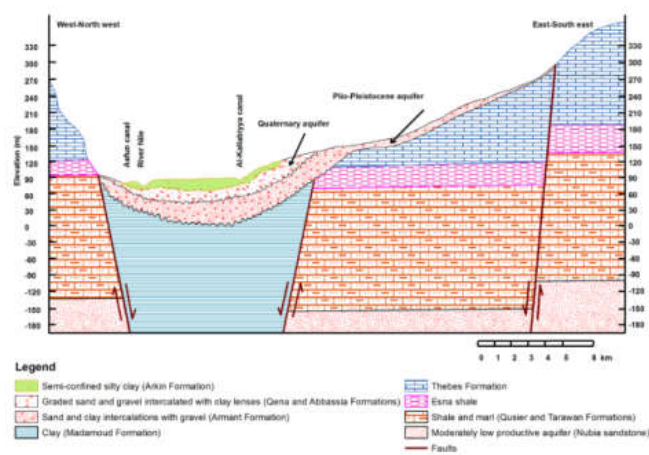

Fig. (5) Hydrogeologic cross section [5]

[12] Shamrukh, M., Corapcioglu, Y., \& Hassona, F., (2001). Modeling the Effect of Chemical Fertilizers on Groundwater Quality in the Nile Valley aquifer, Egypt, Groundwater, Vol. 39, No. 1, PP.59-67.

[13] RIGW/IWACO, (1997). Water Quality Monitoring Programme (TN/70.00067/WQM/97/20).

[14] Ayman, A., (2009). Land Use Change and Deterioration of Pharaonic Monuments in Upper Egypt, Journal of Engineering Science, Assiut University, Vol. 37, No. 1, pp.161177 ,

[15] Awad, A., ElArabi, N \& Hamza, S., (1997). Use of Solute Chemistry and Isotopes to Identify Sources of Groundwater Recharge in the Nile Aquifer System, Upper Egypt, Ground Water, Vol. 35, No. 2, p. 223-228. 


\section{Environmental Impacts}

The study area is hot, dry and rainless in summer and mild with rare rainfall in winter. Its temperature depends on the solar energy, especially the actual hours of sunshine. The distribution of temperature and relative humidity shows that while the lowest temperature of the year is recorded in January, with an average value of $23.05 \mathrm{C}^{\circ}$, the highest one is in June with an average value of $41.12 \mathrm{C}^{\circ}[16]$. Rains are rare, randomly precipitated and vary in amount all over the year; its average annual value is less than $5 \mathrm{~mm} /$ year. The annual mean value of wind speed is $8.00 \mathrm{~m} / \mathrm{sec}$ at Luxor. In the study area, evaporation and evapotranspiration increase in summer and decrease in winter. They are between $4.29 \mathrm{~mm} /$ day and $13.24 \mathrm{~mm} /$ day. The annual mean of relative humidity is between $25.3 \%-53.40 \%$ [2]

\section{Deterioration of sandstone cement at Luxor temple}

The composition of the framework of the granules indicates the date of the deposition of these granules. It is well known that natural sandstone color because the minerals composition. Ferrous mineral oxides such as hematite give dark reddish color, while Oxy ferrous hydroxide gives a dark brown color of the sand Stones[17].The main cause of deterioration found at Luxor temple is ground water, which affects sandstone, especially the cement materials which cement the particle grains. Calcium carbonate $\left(\mathrm{CaCO}_{3}\right)$ may be the most common kind of cement and silica $\left(\mathrm{SiO}_{2}\right)$ comes second, iron oxides, gypsum and other minerals are the least common [18]. During the deposition process of the sandstone, the particles are placed at varying distances, where the force of attraction

[16] Luxor meteorological station, 2012.

[17]Hajpa,'1, M., \& To“ro"k A., (2004), Mineralogical and color changes of quartz sandstones by heat, Environmental Geology 46, P. 311-322..

[18] Danber, K., (1975). The Principles of Stratigraphy, Moscow, Pp. 26-28. 
equals the force of repulsion [19]. Mineralogically, sandstones mainly consist of quartz, feldspars and lithic or rock fragments [20]. While Quartz may be single grains or polycrystalline aggregates, feldspars include both alkali feldspars and plagioclase. The sandstone of Luxor temple contains ferric oxyhydroxides in the form of crystals, such as goethite or amorphous crystals of the limonite kind. The latter dye the grains of sand, especially those of quartz giving the sandstone a yellowish-ochre color. In addition, the dehydration of these oxyhydroxides causes a change of the sandstone's structure and color; that reddish hues of the hematite become more intense [21]. Sandstone is medium grained sedimentary rock formed by the cementation of sand grains. The basic components of sandstone are framework grains (sand particles) which supply the rock's strength [22]. It is noted that both types of porous materials can absorb a high amount of water. Hence, the study of variation in the original physical behavior of the porous materials can be the first step in defining the effectiveness or otherwise of treatments used in conservation. One of the problems anticipated in interventions on Luxor temple is the evaluation of the load-bearing capacity of its masonry (Fig. 1). On one hand, reactions can be calculated using an equation. For such structures, forced deformations (i.e., settlement of support, shrinkage, temperature changes...etc.) [23] (Fig. $6 \&$ \&). In addition, the deterioration of sandstone in polluted regions mainly involves deterioration by air

[19]Ruedrich, J., Bartelsen, T., Dohrmann, R ., (2011). Moisture Expansion as a Deterioration Factor for Sandstone Used in Buildings, Environmental Earth Sciences, Vol. 63, Issue 7, pp. 1545-1564.

[20] Boggs, S., (1992). Petrology of Sedimentary Rock, New York, P. 163.

[21]Urzì, C., Criseo, G., Krumbein, W. E., Wollenzien, U., \& Gorbushina, A., (1993). Are colour changes of rocks caused by climate, pollution, biological growth, or by interactions of the three? In M.-J. Thiel (Ed.), Conservation of stone and other materials, pp. 279-286.

[22] Parker, S., (1988). Mc Grow-hill Encyclopedia of the Geological Science, New York, P.570.

[23] Abd EL Rahman, S., (1996). Structural Analysis and Mechanics, Cairo, P.151. 
pollution [24]. Calcite leaching is one of the most serious consequences of weathering in monumental calcareous sandstones. While the porosity of the rocks increases continuously, mechanical strength decreases due to the loss of the inter-granular binding material [25]. Stone decay mainly belongs to the following typologies: deposits on the stone surface (i.e., salts deposits-efflorescence-inside and black crusts on the outside part of the building [26]. Water passes to the surface and the crystals of salt deposit on the external surface. Visible efflorescence is formed when the solution moves towards the surface of the stone. When it is slower than the rate of drying, water evaporates by diffusion from the pores, resulting in solute crystallizing within the stone, at varying depth. However, this process takes place without any visible alteration of the stone [27]. It was found that urban rain will dissolve the surface of $\mathrm{CaCO}_{3} 50$ times, at least, faster than unpolluted rain [28]. On the contrary, stone conservation requires, in the first place, an identification of deterioration [29]. In addition, deterioration and weathering investigation revealed many types of deterioration on the walls, e.g. cracks, powdering and salt crystallization. Many of them are caused by a rising of groundwater level, causing loss of cohesion between the grains. The walls also contain some aggregates of salts.

[24] Nord, A., and Tronner, K., (1995). Effect of Acid Rain on Sandstone: The Royal Palace and the Riddarholm Church, Stockholm, Water, Air and Soil Pollution, Vol. 85, PP.2719-2724.

[25] Tiano, P., (1995). Stone Reinforcement by Calcite Crystal Precipitation Induced by Organic Matrix Macromolecules, Studies in Conservation 40,Issue3, PP.171-176

[26] Torfs, K., Grieken, V., Zezza, F., García N., \& Macrí F., (1997). The Cathedral of

Bari, Italy: Environmental Effects on Stone Decay Phenomena, Studies in Conservation, Vol. 42, PP. 193-206.

[27] Rossi-Manaresi, Tucci, R., 1991, Pore structure and the disruptive or cementing effect of salt crystallization in various types of stone, Studies in Conservation, 36, pp. 5358 .

[28] Thomson, G., Raymond, W., (1974). The PH of Rain and the Destruction of Alkaline Stone, Studies in Conservation, Vol. 19, Issue 3, PP.190-191.

[29] Rossi R., (1976). The conservation of stone, Bologna, P.297. 


\section{Soil role of Deterioration at Luxor temple}

When groundwater in the temple's foundations evaporates, it leaves salts behind (Fig. $2 \& 4$ ). Which are the ultimate product of rock weathering [30]. Moisture contributed to weathering through purely physical mechanisms (frost splitting) by acting as a transport medium for salts in dissolution and recrystallization processes or through chemical reactions [31]. Although, the processes of chemical weathering entirely relied on the agency of water, the role of soil moisture was highly variable; it depends not only on the other budget's factors but also on the capacity of a soil to hold water gained by infiltration [32].The processes of wetting and drying formed stresses on soil and rocks in the temple (Fig.8). Furthermore, their cycles caused cracking and flaking [33]. Traditionally, the term "drainage" referred to the rate of water's movement in a system. Soils of Luxor temple had a fairly rapid rate of water movement and it is continuously anaerobic. Its natural stones suffered from different kinds of degradation. For example, wetting-drying periods created corresponding dissolution-condensation cycles of salts [34] (Fig. 4). Hence, in soil microbiology, enzyme tests were commonly used to estimate metabolic activity for quantification, the dehydrogenase activity (DHA). The frequency of these micro-

[30] Ayman, A., (2015). Preliminary Investigation of Impact of Land Use Change and Hydrogeologic Conditions on Deterioration of the Temple of Medamud, Luxor, Egypt, International Journal of Environment \& Water, Vol. 4, Issue 2, P.104-117.

[31] Fitzner, B., Heinrichs, K., \& La Bouchardier, D., (2003). Weathering Damage on Pharaonic Sandstone Monuments in Luxor - Egypt, Building and Environment, Vol. 38, Issues 9-10, Building Stone Decay, Pp.1089 - 1103.

[32] McCabe, S., Smith, B., Adamson, C., Mullan, D., \& Mcallister, D., (2011). The "Greening" of Natural Stone Buildings: Quartz Sandstone Performance as a Secondary Indicator of Climate Change in the British Isles, Atmospheric and Climate Sciences, 1, Pp.165-171.

[33] Peter, J., (1982). The Surface of the Earth: an Introduction to Geotechnical Science, London, P.27.

[34] Sabbioni C., \& Zappia, G., (1992). Decay of Sandstone in Urban Areas Correlated with Atmospheric Aerosol, Water, Air and Soil Pollution, Vol. 63, PP.305 - 316. 
organisms on weathered stone indicated that they played a part in the process of deterioration in the temple [35].

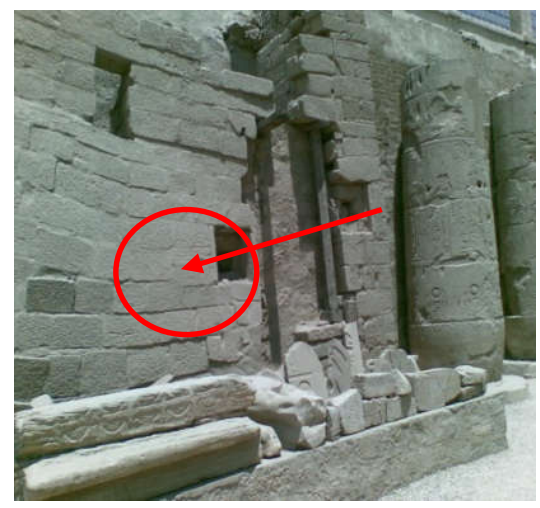

Fig. (6) Differential tendency on the walls of Luxor temple

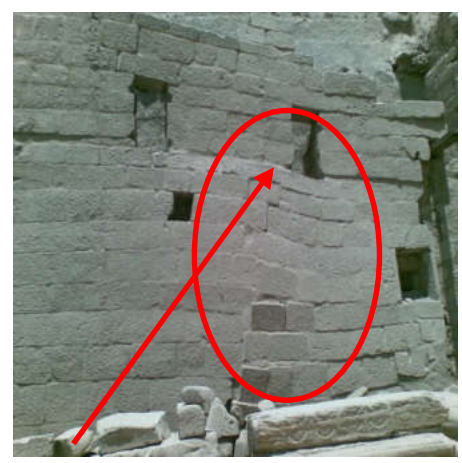

Fig. (8) Differential tendency on the walls of Luxor temple

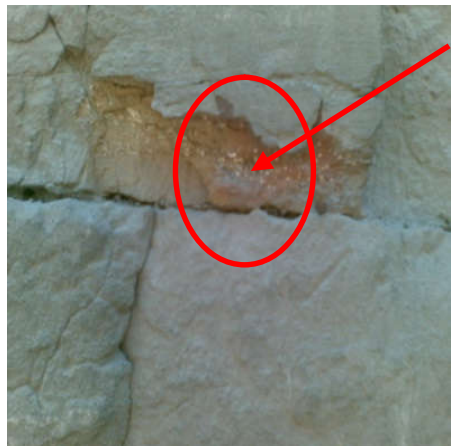

Fig. (7) Stress on the lower parts of Luxor temple's walls

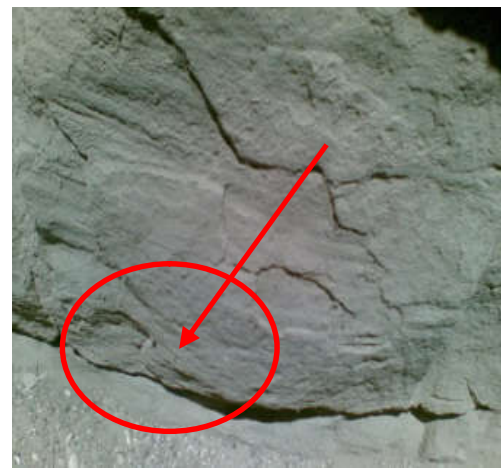

Fig. (9) Soil on the lower parts of Luxor temple's walls

[35] Turkington, A., \& Paradise, R., (2005). Sandstone Weathering: A Century of Research and Innovation, Geomorphology, Vol. 67, issue1, Pp.229-253. 


\section{Materials and Methods}

Samples were collected from several locations of the friable layers on the walls at Luxor temple. They were examined to provide information about the crystal shape, structural state and morphology of the minerals. Furthermore, defining and description of the sandstone minerals and physicochemical alteration.

\section{Mineralogical composition}

The mineralogical composition of the sample's powder was analyzed using X-ray diffraction (Philips X-ray diffraction equipment model $\mathrm{PW} / 1710)$ with monochromatic, $\mathrm{Cu} \mathrm{k}$-á radiation $(1.542=\mathrm{A} \AA)$ at $40 \mathrm{kV}$ and $35 \mathrm{~mA}$ at X-ray diffraction lab, Physical Department, Faculty of Science, Asyut University, Egypt. They were recorded from 4 to $90^{\circ} 2 \theta$. The reflection peaks were between 4 and $90^{\circ} 2 \theta$ with $0.06 \% / \mathrm{m}$ in speed, corresponding spacing $(\mathrm{d}, \AA)$ and the relative intensities $\left(\mathrm{I} / \mathrm{I}^{\circ}\right)$ were obtained [36]. Diffraction charts and relative intensities were studied and compared with ICDD files.

\section{Scanning Electron Microscope (SEM-EDX)}

SEM images of crusts and salt samples were obtained from SEM of (JEOL JSM5500LV) to identify textural and mineralogical changes of the stone and altered stone surfaces. EDX was also used (model 6587).

\section{Chemical analysis by $\mathrm{X}$-ray fluorescence (XRF)}

Elemental analysis was conducted using wavelength dispersive XRF spectrometry (Axios advanced, sequential wd_XRF Spectrometer, 
PANalytical 2005) at the analysis and consulting unit, National Research Center in Cairo.

\section{Results}

\section{Mineralogical study}

XRD patterns showed that quartz $\left(\mathrm{SiO}_{2}\right)$ was the main component of the temple's sandstone, with subordinate amounts Calcite $\left(\mathrm{CaCO}_{3}\right)$ and halite $(\mathrm{NaCl})$, thenardite $\left(\mathrm{Na}_{2} \mathrm{SO}_{4}\right)$ \& gypsum $\left(\mathrm{CaSO}_{4} \cdot 2 \mathrm{H}_{2} \mathrm{O}\right)$ (Fig.10 a \& b). These results proved that the stone used in the temple was Nubian sandstone [37]. Damage to sandstone was caused by the mechanical stress, which was induced by halite, thenardite \& gypsum crystallization cycles and calcite which may be cement in sandstone.

[37] Saleh, S., Helmi, F., Kamal M., \& El-Banna, A., (1992). Study and consolidation of sandstone: temple of Karnak, Luxor, Egypt, Studies in conservation, 37, (2), pp.93-104. 


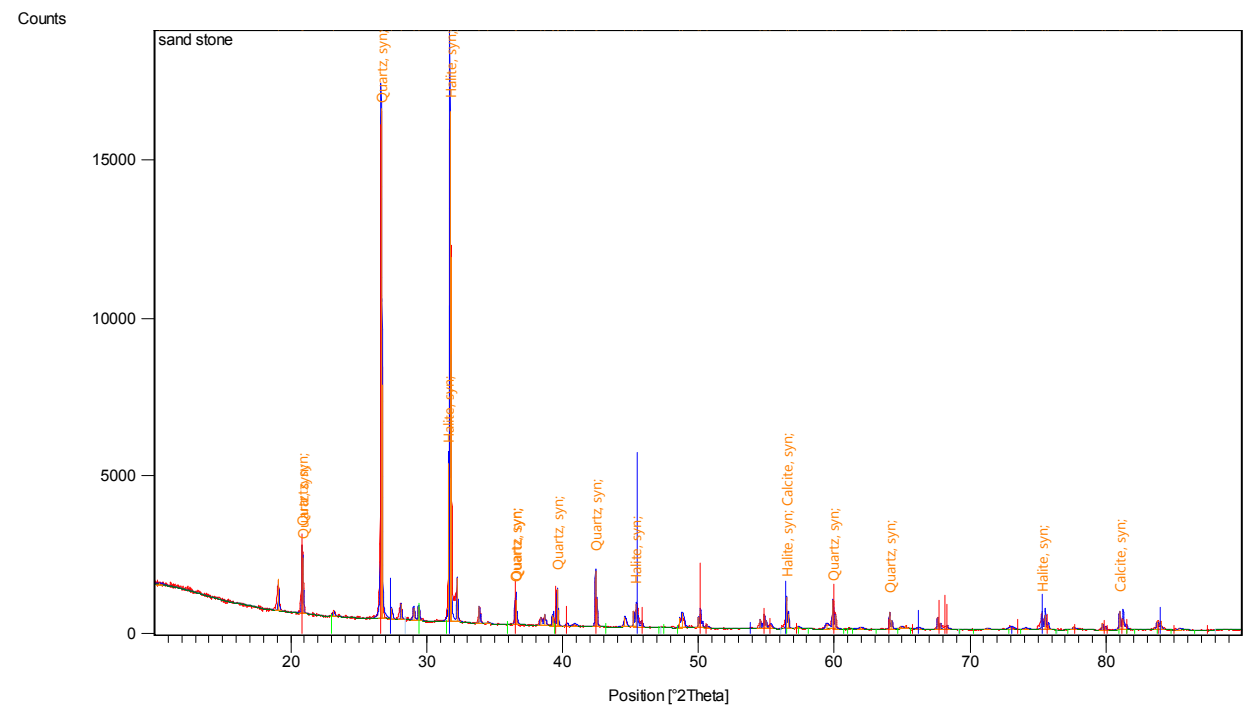

a

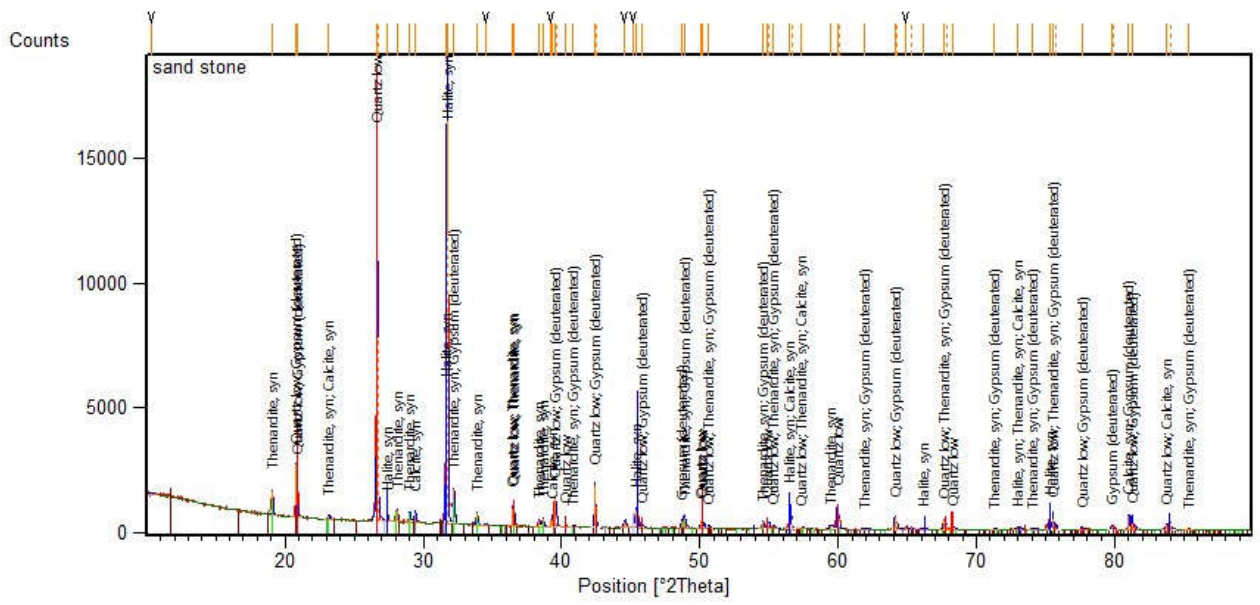

$\mathrm{b}$

Fig. (10 a\&b) A sample of sandstone taken from Luxor temple analyzed by XRD. 


\section{Petrographic Study}

Samples taken from Luxor temple were examined under the polarized microscope and showed that, the percentage of quartz is the highest as it reached $94 \%$ and it took different forms. Other components were as follows: feldspar (5\%), rock fragments $(0.5 \%)$, and cement materials $(10 \%)$. It was also found that the percentage of porosity and permeability was high [38] (Fig.11a, c). Some clay minerals (Fig.11a, c) and iron oxides were also found. Crystals of quartz appeared unequal in their dimension and volumes; they were of great and moderate granulation. Furthermore, it was indicated that angular quartz granules were transformed into semi-angular, showing that they didn't move far during the processes of deposition (Fig.11b, d). In other samples, quartz crystals were rounded and semi-rounded and they moved far during the processes of deposition. There was also an erosion of the edges of some crystals and that extended to the interior part. These results were supported by XRD examination showing that quartz was the main compound with little percent of salts (halite $\mathrm{NaCl}$ ).

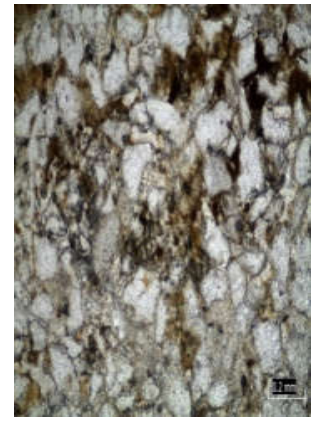

a

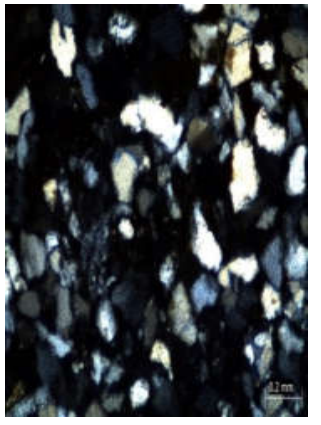

$\mathrm{b}$

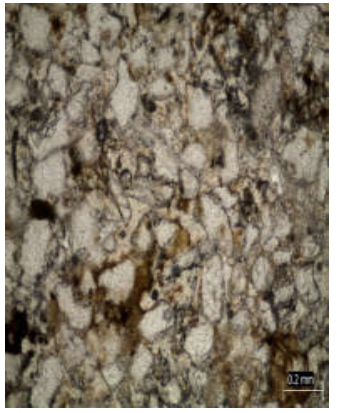

C

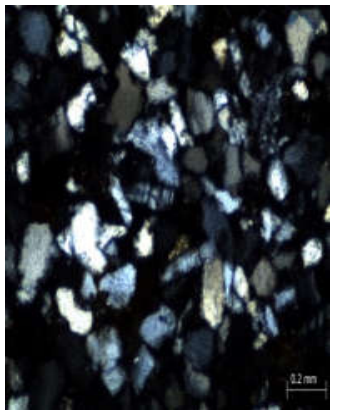

d

Fig. (11) A sample of sandstone from Luxor Temple X25

[38]Prince, C., Ehrlich, R., \& Carr, M., (1999). The Effect of Sandstone Micro Fabric upon Relative Permeability end Points, Journal of Petroleum Science and Engineering 24, p. $169-178$. 


\section{Scanning electron microscope (SEM)}

The samples studying by SEM were identified as quartz $\left(\mathrm{SiO}_{2}\right)$

(Fig.12a.b.c.d) and other salts were submitted by XRD and EDX and XRF such as halite $(\mathrm{NaCl})$ and gypsum $\left(\mathrm{CaSO}_{4} \cdot 2 \mathrm{H}_{2} \mathrm{O}\right)$ and notice decayed of grains of quartz (Fig.13 a.b.c.d). Samples show a damage of cement materials and a breaking in the granules of sandstone (Fig.12a, b). Other samples show a differential of quartz grains, and a collapse of the stone's internal structure (Fig.13c,d).

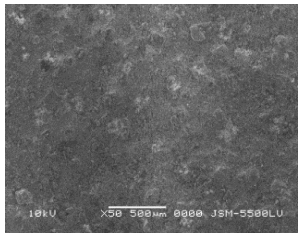

a

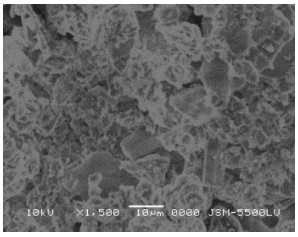

$b$

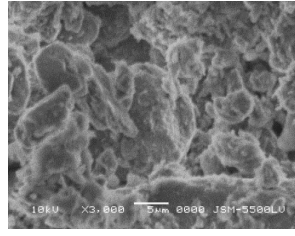

C

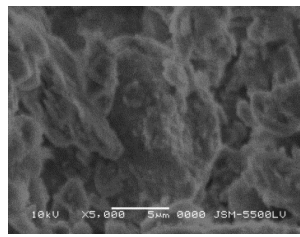

d

Fig. (12) A sample of sandstone examined under SEM, showing the

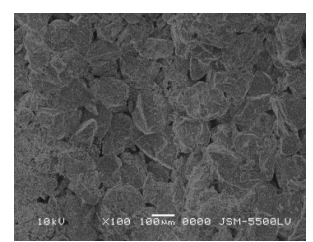

a

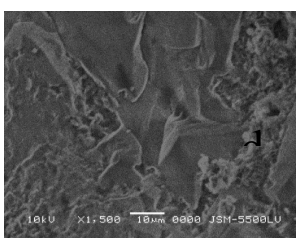

b

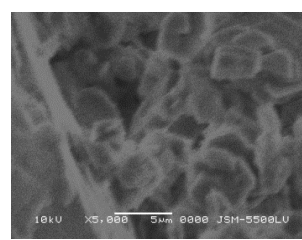

$\mathrm{c}$

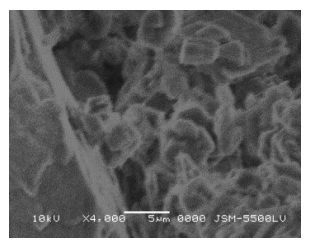

d

Fig. (13) A sample of sandstone under SEM, illustrating the damage of cement materials and the differential of quartz grains form 


\section{Bulk Elemental Analysis by EDX}

EDX micro analytical methods were conducted to identify the samples and evaluate their components which indicates that the elemental arrangement of the samples collected from different places could be put in a decreasing order according to their concentration as follow: $\mathrm{Si}(78.92-85.89 \%), \mathrm{Al}(6.09-7.15 \%), \mathrm{Fe}$ (5.81-2.56\%), K (4.65-1.95\%), Ti (3.77-2.06\%) and Ca (0.76$0.39 \%$ )(Fig.14) (Tab.1)This helped in understanding the weathering mechanisms affecting the temple, in second sample $\mathrm{Si}(77.12-84.32 \%)$, Al (6.94-8.09\%), Fe (6.44-2.88\%), K (4.321.84\%), Ti (3.93-2.28\%) and Ca (2.24-0.59\%) (Fig.15) (Tab.2). The first and second samples contained $\mathrm{Si}$ (as the main component). However, the absence of chlorine $(\mathrm{Cl})$ and sodium $(\mathrm{Na})$ indicated the non-crystallization of halite on the wall reliefs. The analysis also indicated a low concentration of calcium $(\mathrm{Ca})$ that indicated the existence of gypsum and anhydrite salts on the sandstone. In addition, the moderate amount of Aluminum (Al) and potassium $(\mathrm{K})$ could be attributed to feldspars and phyllosilicates. On the contrary, the presence of relatively high amounts of iron and small amounts of titanium was attributed to the origin of these samples, atmospheric pollution and presence of accessory minerals such as $\mathrm{Fe}$ - Ti bearing phases; they played a significant role in deterioration. 


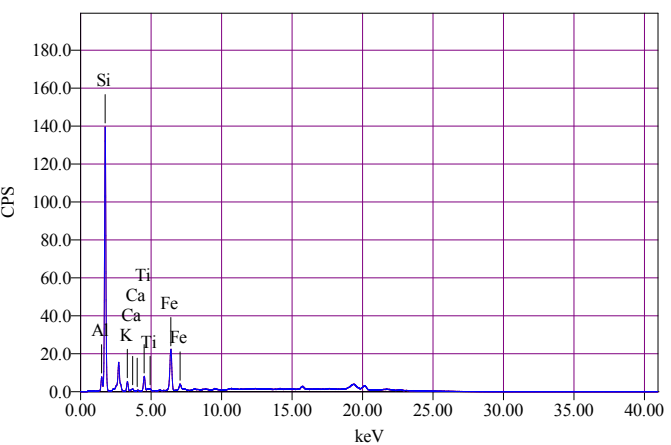

Fig. (14): EDX spectrum of the sandstones (under study)

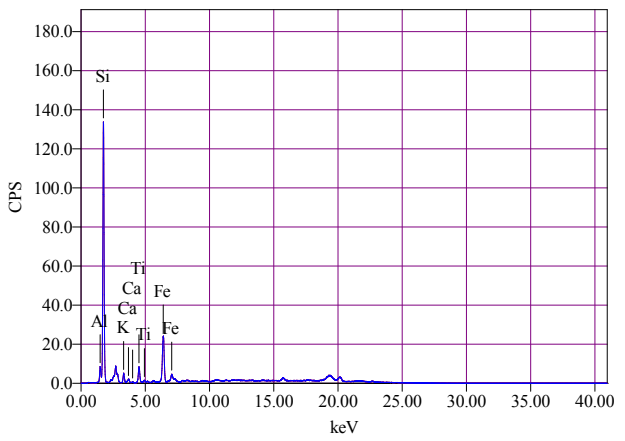

Fig. (15): EDX spectrum of the sandstones (under study)
Table (1): Quantitative EDX microanalysis (compound \%) of the value spot sandstones

\begin{tabular}{|l|l|l|l|}
\hline Element & $\mathrm{ms} \%$ & Oxide & $\mathrm{ms} \%$ \\
\hline $\mathrm{Al}$ & 6.0947 & $\mathrm{Al}_{2} \mathrm{O}_{3}$ & 7.1467 \\
\hline $\mathrm{Si}$ & 78.9230 & $\mathrm{SiO}_{2}$ & 85.8918 \\
\hline $\mathrm{k}$ & 4.6501 & $\mathrm{~K}_{2} \mathrm{O}$ & 1.9453 \\
\hline $\mathrm{Ca}$ & 0.7592 & $\mathrm{CaO}$ & 0.3926 \\
\hline $\mathrm{Ti}$ & 3.7672 & $\mathrm{TiO}_{2}$ & 2.0611 \\
\hline $\mathrm{Fe}$ & 5.8058 & $\mathrm{Fe}_{2} \mathrm{O}_{3}$ & 2.5624 \\
& & & \\
\hline
\end{tabular}

Table (2): Quantitative EDX microanalysis (compound \%) of the value spot sandstones.

\begin{tabular}{|l|l|l|l|}
\hline \multicolumn{2}{|l|}{ Elementms\% } & Oxide & $\mathrm{ms}^{\circ} \%$ \\
\hline $\mathrm{Al}$ & 6.9397 & $\mathrm{Al}_{2} \mathrm{O}_{3}$ & 8.0936 \\
\hline $\mathrm{Si}$ & 77.1218 & $\mathrm{SiO}_{2}$ & 84.3219 \\
\hline $\mathrm{k}$ & 4.3238 & $\mathrm{~K}_{2} \mathrm{O}$ & 1.8388 \\
\hline $\mathrm{Ca}$ & 1.2414 & $\mathrm{CaO}$ & 0.5922 \\
\hline $\mathrm{Ti}$ & 3.9309 & $\mathrm{TiO}_{2}$ & 2.2776 \\
\hline $\mathrm{Fe}$ & 6.4423 & $\mathrm{Fe}_{2} \mathrm{O}_{3}$ & 2.8759 \\
\hline
\end{tabular}




\section{Chemical analysis by XRF}

Chemical analysis under XRF revealed that it contained the following: $\mathrm{SiO}_{2}$ (95.39-95.22- 95.27\%), $\mathrm{AI}_{2} \mathrm{O}_{3}$ (0.79- 0.75- 0.77\%), $\mathrm{Fe}_{2} \mathrm{O}_{3}$ tot. (0.34- 0.32- $\left.0.35 \%\right), \mathrm{CaO}(0.28-0.30-0.27 \%)$, $\mathrm{Na}_{2} \mathrm{O}$ (0.44- 0.47- $\left.0.45 \%\right), \mathrm{SO}_{3}$ (0.29- 0.27- $\left.0.25 \%\right)$, CI (0.400.38- 0.37\%), $\mathrm{P}_{2} \mathrm{O}_{5}$ (0.05- 0.07-0.06\%). While $\mathrm{CaO}$ and $\mathrm{SO}_{3}$ indicated the presence of gypsum, $\mathrm{Na}_{2} \mathrm{O}$ and $\mathrm{Cl}$ indicated Halite. $\mathrm{P}_{2} \mathrm{O}_{5}$ may be to mineralogical composition of sandstone or was found as a result of the problem of Sewage around the site of the temple (Tab.3). 
Table (3) Main Constituents Wt\% of Sandstone - Luxor Temple

\begin{tabular}{|l|l|l|l|}
\hline $\begin{array}{l}\text { Main } \\
\mathrm{Constituents} \%\end{array}$ & $\begin{array}{l}\text { Sandstone- } \\
\text { Luxor } \\
\text { Temple } \\
\text { a }\end{array}$ & $\begin{array}{l}\text { Sandstone }- \\
\text { Luxor Temple } \\
b\end{array}$ & $\begin{array}{l}\text { Sandstone- } \\
\text { Luxor } \\
\text { Temple } \\
\text { c }\end{array}$ \\
\hline $\mathrm{SiO}_{2}$ & 95.39 & 95.22 & 95.27 \\
\hline $\mathrm{TiO}_{2}$ & 0.40 & 0.43 & 0.42 \\
\hline $\mathrm{AI}_{2} \mathrm{O}_{3}$ & 0.79 & 0.75 & 0.77 \\
\hline $\mathrm{Fe}_{2} \mathrm{O}_{3}$ tot. & 0.34 & 0.32 & 0.35 \\
\hline $\mathrm{MgO}$ & 0.12 & 0.14 & 0.11 \\
\hline $\mathrm{CaO}$ & 0.28 & 0.30 & 0.27 \\
\hline $\mathrm{Na}_{2} \mathrm{O}$ & 0.44 & 0.47 & 0.45 \\
\hline $\mathrm{K}_{2} \mathrm{O}$ & 0.16 & 0.19 & 0.17 \\
\hline $\mathrm{P}_{2} \mathrm{O}_{5}$ & 0.05 & 0.07 & 0.06 \\
\hline $\mathrm{SO}$ & 0.29 & 0.27 & 0.25 \\
\hline $\mathrm{CI}$ & 0.40 & 0.38 & 0.37 \\
\hline $\mathrm{LOI}$ & 1.27 & 1.39 & 1.45 \\
\hline $\mathrm{Cr} \mathrm{O}_{3}$ & 0.011 & 0.012 & 0.011 \\
\hline $\mathrm{MnO}$ & 0.011 & 0.011 & 0.010 \\
\hline $\mathrm{NiO}$ & 0.004 & 0.003 & 0.003 \\
\hline $\mathrm{CuO}$ & 0.002 & 0.001 & 0.002 \\
\hline $\mathrm{Y}_{2} \mathrm{O}_{3}$ & 0.001 & 0.001 & 0.001 \\
\hline $\mathrm{ZrO}$ & 0.036 & 0.035 & 0.035 \\
\hline $\mathrm{SrO}$ & 0.002 & 0.002 & 0.002 \\
\hline
\end{tabular}

\section{Discussion and conclusion}

The microscopic examination of several thin sections revealed that sandstone grains were affected by mechanical breakage and chemical processes producing micro-fractures and cleavages. This commonly dissected the quartz grains into several sub-individual grains. In addition, the interaction of feldspar grains with soluble salts was one of the important alteration processes in sandstone.

SEM micrographs illustrated some alterations, such as cracks and pores. Furthermore, XRD results confirmed the petrographic examination, SEM micrographs and EDX analysis. They were compared to define the alteration in sandstone grains and its rate with 
time. This would help in evaluating sandstone's components under the present environmental conditions. Furthermore, many aspects of deterioration were found.

The appearance of black crust was the most prominent aspect of deterioration as the dirt spread heavily on the sandstones, especially on some of the sites that were not subject to any cleanup programs. The high concentration of air pollutants was a clear manifestation of weathering a result of the interaction between the chemical and physical properties of the stone and their environmental conditions.

This interaction between the stones and the atmosphere created a very specific surface environment in terms of the content of moisture and chemicals. In addition, the movement of water caused an increase in the rate of deterioration affecting them. Consequently, the structure of sandstone gradually became weaker by biological, physical and chemical processes. This was accompanied by an increase in pressure on the stone.

The high concentration of sodium $(0.7$ - 4.2\%) and chlorine (1.7 $15.5 \%$ ) may be attributed to the crystallization of halite salt on the walls. These ions may be created from groundwater and the dissolution of halite from soil and sediments in it. A high concentration of sulfate (15 - 47.4\%) and calcium (40.8 - 58.7\%) ions which may be attributed to the crystallization of gypsum and anhydrite salts on the walls. The most common decayed salts are sulfate, chloride and nitrate anions, phylite, greenstone and pentinite grains [39].

These factors increased damage, causing an increase of the pore's diameter (less than $1 \mathrm{~mm}$ ), particularly through the crystallization of salts affecting the mechanical and physical properties that weaken or increase the deterioration of sandstone. The proportion 
of clay materials found as a carnivorous was a reason of increasing the rates of damage due to increasing and shrinking sandstone's exposure to moisture and drought.

In conclusion, different factors influenced the sandstones of the temple, but in various degrees, causing deterioration. Accordingly, some strategic plans have to be conducted to maintain them by controlling these factors to decrease the rates of future deterioration. They must, above all, stop water's penetration through the pores. Implementation barriers should be used to reduce salts in the pores through the use of various compresses and increasing the mechanical resistance of sandstone, using some stimulants materials, especially in areas prone to high degrees of deterioration.

\section{Recommendations}

Luxor Temple is one of the more temples, which greatly affected the ground water where it is located in an urban area surrounded by an agricultural area. And threatens to leak water down the Luxor Temple, which produces water for irrigation and agricultural sewage from populated areas sandstone is affected significantly because of its properties of high absorption of water, due to its interaction dramatically with the surrounding environmental conditions which would lead to the deterioration of the sandstone so you must take significant measures and plans for therapeutic urgency to the problem of ground water and the high levels of ground water and is considered the renewal of the sewerage network and upgrading are sufficient network of agricultural drainage surrounding the area of the main plan stages of treatment in addition to the use of some tonic modern materials that have been tried in proportion to the nature of the sandstone Temple of Luxor However stationed by the 
environmental nature stones and sand. It should take strong measures in terms of ways to use and carried out by the coach a team where the bad use of the methods of treatment can be the biggest deterioration occur than it was before treatment sandstone that is because of the sandy stone exhibition of weathering of great sensitivity. It should study the amount of water leaking down the sandstone Temple of Luxor in addition to monitoring the constant changes, both agricultural and urban surrounding the Temple of Luxor. 
فحص الاثار البيئية علي كتل الحجر الرملي بمعبد الاقصر ومفاهيمه الحفاظ عليها

د. العشماوى عبد الكريم أحمد

المخص:

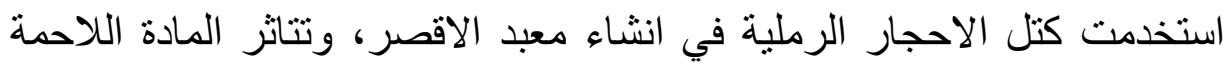

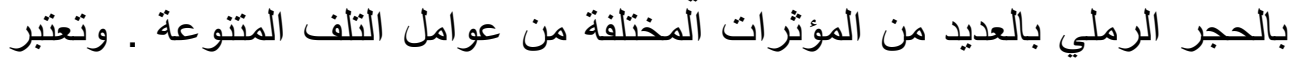

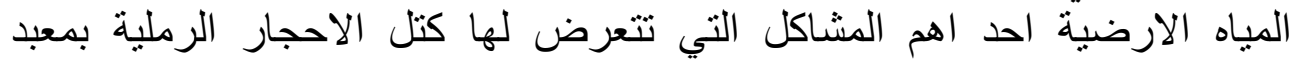

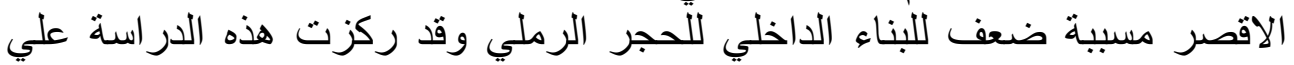

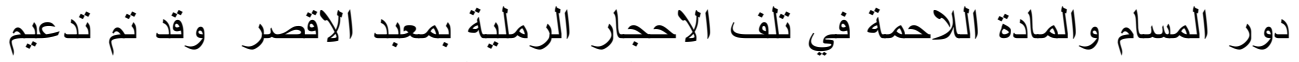

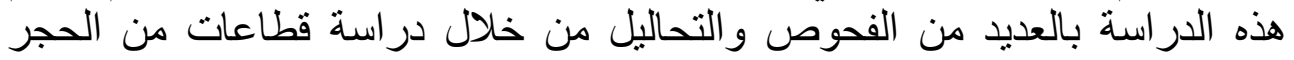

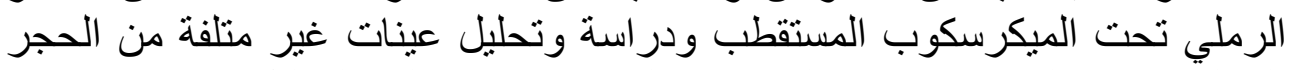

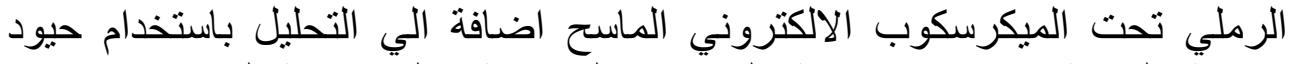

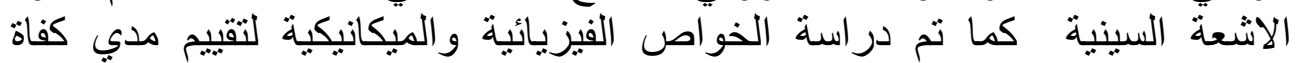

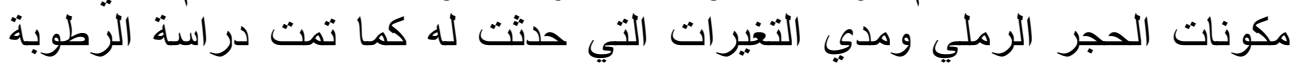

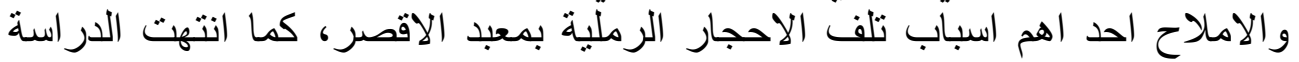

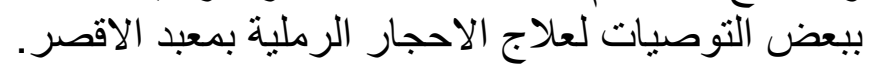

